J. Linguistics 58 (2022), 807-845. (O) The Author(s), 2022. Published by Cambridge University Press. This is an Open Access article, distributed under the terms of the Creative Commons Attribution licence (https://creativecommons.org/licenses/by/4.0/), which permits unrestricted re-use, distribution, and reproduction in any medium, provided the original work is properly cited.

doi: $10.1017 / \mathrm{S} 0022226721000426$

\title{
The syntax of inner aspect in Hungarian ${ }^{1}$
}

\author{
ÉVA KARDOS \\ University of Debrecen \\ IMOLA-ÁGNES FARKAS (1) \\ Babeș-Bolyai University
}

(Received 23 October 2019; revised 29 October 2021)

This paper is concerned with the syntactic representation of inner aspect in Hungarian. We contribute to the extant research on inner aspectual markers by providing an analysis of entailed versus implied telicity as well as the (non)maximality effects with which telic predicates are associated. Although we focus on the grammar of Hungarian, we also draw parallels between typologically different languages like Finno-Ugric (e.g. Hungarian and Finnish) and Germanic (e.g. English) regarding their inner aspectual marking strategies, and the interaction of inner aspect and case assignment.

KeYwords: created object, consumed object, Hungarian, inner aspect, pseudo-object, result predicate, verbal particle

\section{INTRODUCTION}

This paper is concerned with the syntactic representation of inner aspect in Hungarian. Although there is a sizeable literature on various aspectual markers such as verbal particles (VPrts), result predicates (RPs), pseudo-objects (POs) or created/consumed

[1] We would like to express our gratitude to Edgar Onea, Gergely Pethô and the three anonymous Journal of Linguistics referees for their detailed and very helpful comments on earlier drafts of this work. Our paper has also benefited from the audiences of the following events: Endpoints, Scales, and Results in the Decomposition of Verbal Predicates (2018), The Beijing Argument Structure and Event Structure Workshop (2018), The 11th Brussels Conference on Generative Linguistics: The Syntax and Semantics of Aspect (2018) and The 14th International Conference on the Structure of Hungarian (2019).

The following abbreviations are used in our glosses and in-text examples: $\mathrm{ACC}=$ accusative, $\mathrm{ALL}=$ allative, $\mathrm{ELA}=$ elative, $\mathrm{ILL}=$ illative, $\mathrm{INF}=$ infinitive, $\mathrm{NOM}=$ nominative, $\mathrm{PL}=$ plural, $\mathrm{POSS}=$ possessive, $\mathrm{PREF}=$ prefix, $\mathrm{PRT}=$ particle, $\mathrm{SG}=$ singular, $\mathrm{SUB}=$ sublative, $\mathrm{sUP}=$ superessive, $\mathrm{TER}=$ terminative and TRA = translative. In addition, although the (verbal) particle and the lexical verb form a prosodic unit and are spelled solid when the particle is immediately before the verb (e.g. megevett), they are consistently spelled with a hyphen (e.g. meg-evett) in the case of both numbered and in-text examples in order for us to be able to render, through the glosses, their precise meaning separately. 
objects (CCOs) (É. Kiss 2004, 2005, 2008a, b; Kiefer 2006; Kardos 2012, 2016, 2019; Farkas \& Kardos 2018, 2019a, b; Farkas 2019, 2020a, 2021; Hegedús 2020), there is no consensus on the right analysis regarding their syntactic behaviour. In this work, our main goal is to attribute the event aspectual interpretations associated with the different marking elements to the syntactic configuration characterizing these elements. There are two main claims that we argue for:

First, in line with previous literature on the syntax of inner aspect (see MacDonald 2008 or Travis 2010), we claim, building on Surányi (2014), that Hungarian also has an aspectual functional projection, called AspP, sandwiched between VP and $v \mathrm{P}$ in the event domain, which is directly responsible for the aspectual interpretations associated with VPrts, RPs and POs. The analysis that we propose in this paper pertains to separable particles with an obligatorily telic function like meg in examples such as János meg-evett egy almát 'János PRT-ate an apple' and János meg-szerelt egy gépet 'János PRT-fixed a machine'. In addition, with respect to the aspectual differences between VPrts/RPs, on the one hand, and POs, on the other hand, we argue, following Kardos $(2012,2016)$ and Farkas \& Kardos (2019a, b), that while the former serve an event-maximalizing function in their respective predicates by virtue of encoding an event-maximalizing operator, the latter have a non-maximalizing function by virtue of encoding an operator that picks out a contextually-defined, non-maximal subpart of the events in the denotation of their verbal predicates. In other words, although members of both classes of aspectual markers give rise to quantized and telic VPs, telicity in the case of the former goes hand in hand with maximality, whereas in the latter case it does not. In minimalist terms, AspP can be characterized in terms of two types of features: it is associated with a [+telic] feature and, in addition to that, a maximality feature as well, which can be valued in one of two ways, i.e. [+maximal] or [-maximal]. Thus, the properties of these two classes of aspectual markers can be described as follows: VPrts/RPs $=[+$ telic, + maximal $]$, POs $=[+$ telic,, maximal $]$.

Second, in accordance with prior literature (e.g. É. Kiss 2008a; Kardos 2012, 2019), we show that telic readings in Hungarian are also available with verbs complemented with CCOs in the absence of any other aspectual marking elements. We show that while telicity in the previous case, i.e. when AspP is present, is an entailment; it is an implicature in the case of creation/consumption predicates, which means that telicity is cancellable in this verb class. Whereas non-cancellable telicity effects will be shown to be exerted by grammatical elements occupying the [Spec, AspP] position associated with the $[+$ telic] feature and, in addition, the [ \pm maximal] feature, characteristic of two subclasses of telic predicates; cancellable telicity will be argued to arise in the absence of a telic structure in the class of creation/consumption predicates. In other words, whereas AspP is projected in the case of aspectual markers with non-cancellable telicity effects, aspectual markers with cancellable telicity effects do not trigger the projection of this phrase. We also assume that in the case of other elements with no telicity effects (e.g. non-telicizing verbal particles or internal arguments other than quantized CCOs appearing in the environment of base verbs) AspP is, again, not projected. 
In this paper we propose the following skeleton for Hungarian telicity-marking elements:

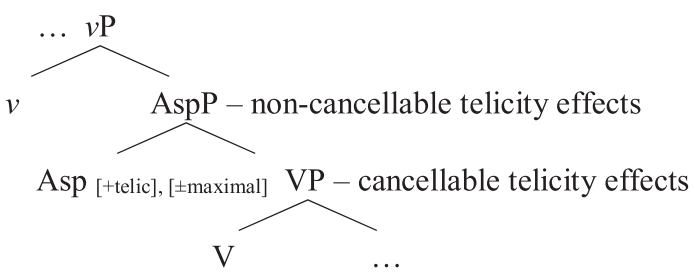

The chief aim of this paper is to provide an analysis of telicity entailments and the lack thereof as well as the (non)maximality effects with which telic predicates are associated by examining the aspectual behaviour of members of (i) the class of VPrts and RPs, (ii) the class of non-subcategorized POs, and (iii) the class of CCOs.

We also find it important to stress at the outset that, as far as verbal particles are concerned, given the complexity of the event structural and argument structural consequences of these elements, we cannot do justice to the richness of the verbal particle system in Hungarian within the confines of this paper. Concerning their event structural effects, telicizing particles like fully grammaticalized meg and particles associated with some lexical information in addition to their telicizing function, such as fel 'up' in fel-mászott a fára 'climbed up the tree', are assumed to exert their telicizing/event-maximalizing effects in [Spec, AspP]. By contrast, particles that do not make the predicate telic may be simply predicative elements, as in the case of $k i$ 'out' in Az ing ki-lóg a nadrágból 'The shirt hangs out of the pants', occupying the specifier of a Pred projection (É. Kiss 2008a). Particles with a purely predicative function are plausibly merged within the VP similarly to result predicates such as ropogósra '(lit.) onto crispy' as in ropogósra sütötte a csirkét 'roasted the chicken crispy', where the latter are also argued to move to [Spec, AspP] to make the predicate telic (see Section 4.1).

The structure of the paper is as follows: In Section 2 we provide a summary of some important generalizations about Hungarian inner aspectual markers based on previous literature and also review some recent syntactic analyses of these marking elements. In Section 3 we present our theoretical assumptions about lexical aspect and grammatical aspect, two distinct, albeit related aspectual categories, as well as the structure of the VP so that we can present our proposal in Section 4 with these assumptions in mind. In Section 5 we discuss some consequences of the proposal focusing on various co-occurrence restrictions pertaining to the different inner aspectual markers. In Section 6 we conclude.

\section{Previous literature on hungarian INNER ASPeCtUAl Markers}

Grammatical aspect (more specifically, perfectivity) has long been at the forefront of attention in the literature on Hungarian (see É. Kiss 2002, Kiefer 2006, among many others), but the study of inner aspect is relatively new in Hungarian 
aspectology. In this section, we review some important generalizations that have been made about inner aspectual markers in prior literature in an effort to lay the groundwork for our analysis in subsequent sections.

\subsection{Some generalizations about telic predicates in Hungarian and across languages}

It is well-known that telic interpretations in Hungarian can arise in the presence of (i) verbal particles (2b), result predicates ( $3 b$ ) or goal-denoting predicates (4b) (see Csirmaz 2008a; É. Kiss 2008a, b; Kardos 2012, 2016); (ii) non-subcategorized pseudo-objects (5b) (see Piñón 2001; Kiefer 2006; Csirmaz 2008b; Farkas \& Kardos 2018, 2019a, b; Farkas 2019, 2020a, 2021); and (iii) subcategorized created/consumed objects (6) (see É. Kiss 2005, 2008a; Kiefer 2006; Csirmaz 2008a; Piñón 2008; Kardos 2019):

(2) (a) János egy óráig/*egy óra alatt súrolt

János one hour.for/one hour under scrubbed

egy kádat.

(strictly atelic)

a tub.ACC

'János scrubbed a tub for/*in an hour.'

(b) János egy óra alatt/*egy óráig meg-súrolt

János one hour under/one hour.for PRT-scrubbed

egy kádat.

(strictly telic)

a tub.ACC

'János scrubbed a tub completely in/*for an hour.'

(3) (a) Péter tíz percig/*tíz perc alatt kalapált

Péter ten minute.for/ten minute under hammered

egy vaslemezt.

an iron.sheet.ACC

(strictly atelic)

'Péter hammered an iron sheet for/*in ten minutes.'

(b) Péter tíz perc alatt/*tíz percig laposra

Péter ten minute under/ten minute.for flat.sub

kalapált egy vaslemezt. (strictly telic)

hammered an iron.sheet.ACC

'Péter hammered an iron sheet flat in/*for ten minutes.'

(4) (a) Péter tíz percig/*tíz perc alatt futott. (strictly atelic)

Péter ten minute.for/ten minute under ran

'Péter ran for/*in ten minutes.'

(b) Péter tíz perc alatt/*tíz percig

Péter ten minute under/ten minute.for

a házba futott.

(strictly telic)

the house.ILL ran

'Péter ran into the house in/*for ten minutes.' 

(5) (a) Mari tíz percig/*tíz perc alatt táncolt. (strictly atelic) Mari ten minute.for/ten minute under danced
'Mari danced for/*in ten minutes.'
(b) Mari táncolt egyet/egy jót. ${ }^{2}$
Mari danced one.Acc/one good.ACC
(strictly telic)
'Mari had a dance/had a good dance.'

(6) (a) Mari egy év alatt/egy évig épített egy házat. (atelic or telic) Mari one year under/one year.for built a house.ACC

'Mari built a house in/for a year.'
(b) Mari tíz perc alatt/tíz percig ivott
Mari ten minute under/ten minute.for drank
egy limonádét.
a lemonade.ACC
'Mari drank a lemonade in/for ten minutes.'

As shown above, all the elements in boldface may result in telicity, but there are differences in their telicity-inducing effects. Whereas the verbal particle meg in (2b), the result predicate laposra '(lit.) onto flat' in (3b), the goal-denoting predicate $a$ házba 'into the house' in (4b) as well as the POs egyet 'one.ACC' and egy jót 'one good.ACC' in (5b) give rise to non-cancellable telicity; the created object egy házat 'a house.ACC' and the consumed object egy limonádét 'a lemonade.ACC' in (6a) and (6b) yield variable telicity, as evidenced by the temporal adverbial test. Crucially, themes alone in the class of non-creation/non-consumption predicates will generally not give rise to telicity irrespective of their referential properties (see (2a) and (3a) above) (for a caveat, see fn. 3 below). Telicity obtains only if a verbal particle like meg, a resultative predicate like laposra '(lit.) onto flat', a goal-denoting predicate like a házba 'into the house' or a pseudo-object like egyet 'one.ACC' appears in the predicate (É. Kiss 2008a; Kardos 2012, 2016).

That verbal particles, result predicates of end state/end location and incremental themes such as created and consumed objects figure in the calculation of telicity has also been widely discussed in the literature with respect to numerous other languages. In English, for example, while themes that have a measuring role are sufficient for telicity to obtain if they are associated with quantized reference (Verkuyl 1993, Tenny 1994, Krifka 1998), resultative predicates like clean in (7b) and verbal particles like up in (8c) also play a role in the aspectual make-up of the sentence in that they ensure non-cancellable telicity. Atelic readings in the environment of these elements are not available provided that the theme has quantized reference (Beavers 2012).

[2] The temporal adverbial test cannot be reliably used to diagnose the telicity of verbal predicates like táncolt egyet 'had a dance' in (5b); see É. Kiss (2004) and Csirmaz (2008b). Instead, another standard telicity test will be used to probe for (a)telicity in the case of this and other similar examples (see Section 4). 
(7) (a) John wiped the table for/in ten minutes.

(atelic or telic)

(b) John wiped the table clean in $/ *$ for ten minutes.

(strictly telic)

(8) (a) Peter ate soup/sandwiches for/*in ten minutes.

(strictly atelic)

(b) Peter ate the soup/the sandwich in/??for ten minutes. (preferably telic)

(c) Peter ate the soup/the sandwich up in/*for ten minutes. (strictly telic)

As pointed out by Levin \& Sells (2009), examples like (7a) are characterized by aspectual duality. A telic reading is available if the theme the table is meant to measure out the event of the verb, whereas an atelic interpretation is also possible if the verbal predicate is understood iteratively. On the other hand, examples like ate the soup/ate the sandwich in (8b) are also characterized by variable telicity, as discussed by Dowty (1979), Hay et al. (1999) and Kardos (2019), among others. In the presence of a resultative predicate like clean or a verbal particle like up, however, the examples in (7b) and (8c) become clearly telic.

As for telicity marking via pseudo-objects, it is more difficult to find examples in other languages whose grammatical behaviour is comparable to that of Hungarian egyet 'one.ACC' and egy jót 'one good.ACC'. Regarding its semantic properties, a somewhat similar telicizing element is the prefix po- in Polish and other Slavic languages (see Piñón 1994). The examples in (9) serve as illustration; the superscript I stands for 'imperfective' and P stands for 'perfective'.
(a) Irenka czytała ${ }^{\mathrm{I}}$ wczoraj gazetę.
Irenka read yesterday newspaper.ACC
'Irenka was reading the newspaper yesterday.'
(b) Irenka prze-czytała ${ }^{\mathrm{P}}$ wczoraj gazete.
Irenka PRZE-read yesterday newspaper.ACC
'Irenka read the newspaper yesterday.'
(c) Irenka po-czytała wczoraj gazetę.
Irenka PO-read yesterday newspaper.ACC
'Irenka read the newspaper (for a while) yesterday.'

(adapted from Piñón 1994: 341 exx. (1a-c))

Piñón (1994) uses a number of diagnostics to show that verbs associated with the prefix po- exhibit features of both perfectives and imperfectives. He also argues that $p o$ - has the meaning of a durative adverbial with a contextual parameter and that given the analysis of this prefix as a derived measure function, verbs like poczytata 'PO-read' are associated with quantized reference, similarly to perfective verbs.

The subsequent discussion will show that Hungarian verbal predicates containing POs like egyet 'one.ACC' also have quantized reference (see Farkas \& Kardos 2018), similarly to predicates containing VPrts or RPs (Kardos 2012, 2016), and their interpretation is also contingent on context. In this respect, they contrast with particle verbs. However, verbs prefixed by $p o$ - are also different from Hungarian egyet-type VPs in that the former allow for-adverbials and disallow the adverbial 
prawie 'almost', while the latter disallow for-adverbials and can co-occur with the adverbial majdnem 'almost', as will be illustrated in Section 4.

As for the semantic effects of verbal particles and resultative predicates in Hungarian, it has also been shown that in neutral sentences (i.e. declaratives without progressive aspect, negation or narrow focus) they impose constraints on themes such that their quantity must be known (É. Kiss 2005). This is exemplified in (10).
(a) *Péter meg-szerelt gépeket.
Péter PRT-fixed machine.PL.ACC
(b) Péter meg-szerelt egy gépet.
Péter PRT-fixed a machine.ACC
'Péter fixed a machine.'

Whereas the bare plural gépeket 'machines' is unacceptable in the environment of the particle verb meg-szerelt 'PRT-fixed' by virtue of having cumulative reference, the theme egy gépet 'a machine', which is interpreted with quantized reference, gives rise to a grammatical sentence with the same verb.

Slavic languages also show a similar behaviour, as has been pointed out by numerous scholars including, for example, Slabakova (2004) and Filip (2008). Here we illustrate this with Polish examples from Filip (2008).

(11) (a) On jadł ${ }^{\mathrm{I}}$ kaszę/oliwki.

he.NOM ate porridge.SG.ACC/olives.PL.ACC

i. He was eating (some/ $\varnothing /$ the) porridge/olives.

'He was eating some of the porridge/olives.'

ii. He ate (some/Ø/the) porridge/olives.

(b) On z.jadi ${ }^{\mathrm{P}}$ kaszę/oliwki.

he.NOM PREF.ate porridge.SG.ACC/olives.PL.ACC

'He ate (up) (all) the porridge/olives.'

(Filip 2008: 250 exx. (38b) and (38a))

What is of interest regarding the data above is that the example in (11b), which contains a perfective verb and a theme expressed by a bare noun, can only be interpreted with specific reference with respect to the theme. The event description in (b) is also obligatorily telic. By contrast, specificity of the theme is not required in (11a), where the sentence contains an imperfective verb, and telicity here is only an implicature as it can be cancelled. As noted by Filip (2008: 251), the interpretation of the theme is contingent on contextual factors.

Another important generalization regarding Hungarian is that events that have an inherent endpoint must be overtly marked (É. Kiss 2008a, b; Kardos 2012, 2016). This is evidenced by the fact that, in the class of non-creation/non-consumption verbal predicates, achievements (12) and degree verbs associated with closed scales (13) (Wechsler 2005) must appear with a verbal particle or a resultative predicate 
(É. Kiss 2008b, Kardos 2016, Hegedûs 2017) in a sentence with a non-progressive, telic interpretation. ${ }^{3}$

János *(meg-)halt.
János PRT-died
'János died.'

(13) János *(ki-)egyenesítette a kötelet.

János PRT-straightened the rope.ACC

'János straightened the rope.'

In (12) the verbal predicate meg-hal 'PRT-die' expresses a dying situation, which is associated with an inherent endpoint, and thus omission of the verbal particle meg is not possible. Likewise, the verb stem egyenesit 'straighten' cannot occur without the particle $k i$ in (13), as this predicate encodes a maximal endpoint, which corresponds to the state of (complete) straightness.

Finally, as already discussed above, the class of telicity markers in Hungarian is heterogeneous. Whereas VPrts, RPs and POs ensure non-cancellable telicity with respect to the verbal predicate, CCOs give rise to aspectual variability. Here we illustrate this further with the examples below:

(a) \#János tegnap meg-tervezett egy házat,
János yesterday PRT-designed a house.ACC
de még nem fejezte be.
but yet not finished PRT
'János designed house yesterday, but he has not finished it yet.'
(b) János tegnap tervezett egy házat,
János yesterday designed a house.ACC
de még nem fejezte be.
but yet not finished PRT
'János designed a house yesterday, but he has not finished it yet.'

As evidenced by the entailment test, meg-tervezett egy házat 'PRT-designed a house' can only be interpreted as telic, whereas tervezett egy házat 'designed a house', which does not appear with a verbal particle, is compatible with an interpretation that the attainment of an endpoint has not been achieved. Telicity in this latter case can be cancelled.

[3] As pointed out by a referee and also Hegedûs (2018), deadjectival verbs like portalanít 'dust' in portalanította a szobát 'dusted the room' and hatástalanít 'deactivate' in hatástalanította a bombát 'deactivated the bomb', which both include the suffix -talan contributing a scale with an endpoint to the predicate, do not require a particle or result phrase for a telic interpretation to become available. However, we agree with Hegedûs (2018) that there is still a strong tendency for Hungarian to express telicity through verb-external marking elements such as verbal particles or result predicates; there are only a few exceptions to this generalization (Hegedús 2018: 12). 
In recent decades, researchers have attempted to represent telicity-marking elements in the syntax of the Hungarian sentence in different ways. We briefly review some of these proposals in the next section.

\subsection{More recent claims concerning the syntax of event aspectual markers in Hungarian}

It is verbal particles and result predicates that have generated the most amount of research in the past few decades regarding aspectualizers in Hungarian. According to the most influential analysis (É. Kiss 2004, 2008a), the verbal particle is a secondary predicate that merges in the postverbal domain of the Hungarian sentence and, in a one-step derivation, moves to the specifier position of PredP, situated above VP, to check the predicative feature of the head, whereas V moves to Pred in the course of the derivation. The telicizing effect of the particle is a direct consequence of its lexical semantics. As discussed in Section 4, this is in contrast to our analysis, as we assume that it is the grammar that is directly responsible for creating telic structures (Borer 2005) associated with verbal particles and result predicates.

In another study, Surányi (2009) advocates a $v$ P-shell analysis of the Hungarian event domain based on Surányi (2006), and proposes a two-step derivation of verbal particles and result predicates whereby they first move from their base-generated postverbal position to [Spec, PredP], sandwiched between $\mathrm{VP}$ and $\nu \mathrm{P}$, and then to [Spec, TP] to check the EPP feature of T.

Another recent analysis of verbal particles is given by Hegedús \& Dékány (2017), where both separable and inseparable particles are addressed. On the one hand, in separable particle verbs like el-fut 'run away', the particle appears in the immediately preverbal position in neutral sentences (i.e. declaratives without progressive aspect, negation or narrow focus) and in a postverbal position in non-neutral sentences (declaratives with progressive aspect, negation, narrow focus, $w h$-interrogatives and imperatives). On the other hand, in inseparable particle verbs like felvételizik 'take an entrance exam' (where $f e l$ is the inseparable particle), the particle appears in the immediately preverbal position in both neutral and nonneutral sentences. The authors take separable verbal particles to be small clause predicates in the complement zone of V. They also claim that separable particles that can occur with inseparable particle verbs such as szét in szét-felvételiztem az agyam 'I got exhausted with taking entrance exams' are merged in a specifier position ([Spec, PredP]) located between VP and $v$ P.

Next, Hegedús (2017) provides a preliminary syntactic account of endpointdenoting elements in Hungarian. Her main concern is the structural characterization of the cross-linguistic variation between verb-framed and satellite-framed languages (Talmy 1985). She points out that Hungarian, a satellite-framed language, differs from verb-framed languages and also from English, another satellite-framed language, in that results/goal points must be separately instantiated in this language. Particles never incorporate into the $\mathrm{V}$ head, and there is no N-to-P incorporation, 
where the resulting compound incorporates into $\mathrm{V}$ in the manner proposed by Hale $\&$ Keyser (2002) for denominal verbs like shelve. On this view, particles appear as $p$ heads in the syntax, where $p$ Ps are complements of $\mathrm{V}$ and the internal argument occupies the specifier of this phrase.

Finally, Surányi (2014) argues for an aspectual functional projection, AspP, flanked by VP and $v$ P, in line with MacDonald (2008) and Travis (2010), thereby directly associating inner aspectual interpretations with the syntactic structure of the Hungarian sentence. On this analysis, verbal particles, goal-point denoting PPs and some other elements such as bare nominals are base-generated in a postverbal position and first move to [Spec, AspP] for the purpose of pseudo-incorporation before they eventually end up in a $v$ P-external position. As will be clear in the subsequent discussion, we side with Surányi (2014) in assuming a $v \mathrm{P}$-medial aspectual functional projection in Hungarian, but also argue that (i) AspP is associated not only with the [+telic] feature but also with the $[ \pm$ maximal] feature, and (ii) telicity may also arise in the absence of AspP in the case of creation/ consumption predicates. These assumptions will allow us to capture the different event structural properties associated with VPrts, RPs, POs and CCOs.

Similarly to particles, POs like egyet 'one.ACC' and egy jót 'one good.ACC' have also been argued to merge within $v \mathrm{P}$ and move to [Spec, PredP] when they precede the (semelfactive) verb. Just like on É. Kiss's (2008a) analysis of verbal particles, the telicity of predicates containing pseudo-objects has been regarded as a matter of semantics (Csirmaz 2008b).

In this work we propose a syntactic analysis of the three classes of aspectual markers discussed so far, where we pay special attention to how the event structural properties characterizing these elements are to be represented in the structure of the Hungarian sentence. Before proposing our analysis, however, we discuss our assumptions regarding the relationship between grammatical aspect and lexical aspect and the structure of the VP in Section 3.

\section{The FRAMEWORK IN A NUTShell}

\subsection{Outer aspect versus inner aspect}

Aspect is a term that has been used to refer to (at least) two distinct domains of study: outer (also called grammatical or viewpoint) aspect and inner (also called lexical or situation) aspect, also referred to as Aktionsart; see Smith (1991). On the one hand, outer aspectual categories are generally encoded by morphological devices or periphrastic constructions. Outer aspect is often responsible for grammatically signalling whether the verbal predicate expresses an ongoing situation or one that is completed. We illustrate this opposition with the following pair of sentences from English:

(15) (a) When Bill came into the office, Sara left through the back door.

(b) When Bill came into the office, Sara was leaving through the back door.

(De Swart 2012: 753 ex. (3)) 
The sentence in (15a) presents both Bill's coming into the office and Sara's leaving through the back door as completed events, where the former precedes the latter in time. By contrast, (15b) expresses Bill's coming into the office as a completed event, whereas Sara's leaving through the back door as ongoing. The two events are described as overlapping; a consecutive reading is not available.

On the other hand, the categories that belong to inner aspect are encoded in the verb phrase by means of inherent aspectual features. As we will see below, inner aspect, a $v \mathrm{P}$-related functional category, can be morphologically encoded for instance by verbal particles.

Evidence for these distinct - albeit related - aspectual categories with respect to Hungarian has been provided by Csirmaz (2008a). Here we only illustrate the perfective-imperfective distinction with the examples in (16), where inner aspect is kept constant; both sentences contain a telic predicate.
(a) Kati fel-mászott a fára.
Kati PRT-climbed the tree.suB
'Kati climbed (up) the tree.'
(b) Kati mászott fel a fára, amikor ...
Kati climbed PRT the tree.sub when...
'Kati was climbing (up) the tree when ...'

The interpretational differences are significant: whereas the perfective and telic (16a) means that Kati climbed up the tree, the progressive and telic (16b) means that Kati was engaged in the event of climbing up the tree when the event of the subordinate clause occurred. The perfective-imperfective contrast is reflected in word-order differences. Whereas in (16a) the particle fel precedes the verb, in (16b) it follows it. Outer aspectual differences are also reflected in the prosody of the Hungarian sentence. Consider (17).
(a) János ivott egy limonádét.
János drank a lemonade.ACC
'János drank a lemonade.'
(b) János ivott egy limonádét, amikor... János drank a lemonade.ACC when ... 'János was drinking a lemonade, when ...'

The sentences in (16a) and (16b), and also in (17a) and (17b), are different regarding the stress pattern they are associated with. Whereas in the (a) examples the verbs bear the main stress, in the (b) examples stress is distributed over the words mászott 'climbed', $\mathrm{fel}$ 'PRT' and fára 'tree.suB' in (16b) and ivott 'drank' and limonádét 'lemonade.ACC' in (17b) (for similar data, see É. Kiss 2002: 63). Noncontrastive topics like Kati and János cannot receive the main stress. For more on Hungarian sentence prosody, see Hunyadi (2002).

In what follows we will keep outer aspect constant, as the analysis of this aspectual category is beyond the scope of this paper. The Hungarian examples in the rest of the paper are meant to receive a perfective interpretation. 


\subsection{The structure of the VP}

As far as the structure of the verb phrase is concerned, we follow MacDonald (2008), Travis (2010) and Surányi (2014) (see Section 2.2) in assuming that they can be split into a lexical $\mathrm{VP}$ and a light $v \mathrm{P}$, and in claiming that there is an inflectional aspectual category sandwiched between these two phrases (called AspP).

The main goal of MacDonald's (2008) analysis is to explore the syntactic nature of inner aspect from a minimalist perspective. With respect to English inner aspect, two independent properties must be taken into consideration. To account for the object-to-event mapping property (i.e. the ability of a nominal expression to affect the aspectual interpretation of a predicate), the author argues for the existence of an aspectual phrase (AspP) within the verbal domain (more exactly, between $v \mathrm{P}$ and VP), which is implicated in the aspectual interpretation of the predicate and determines a domain of aspectual interpretation. Moreover, the Agree relation with Asp is the syntactic instantiation of the object-to-event mapping (and it is always the nominal expression closest to Asp that enters this mapping relation). To capture properties related to event structure, the author argues for the existence of interpretable event features that enter the syntax on certain heads (Asp, V), and which express whether the event has a beginning $(<\mathrm{ie}>$ feature) and/or an end $(<\mathrm{fe}>$ feature). These event features contribute to the aspectual interpretation of the sentence.

An important consequence of AspP is that it is only elements that are within the domain of aspectual interpretation that can contribute to the aspectual interpretation of the predicate. In other words, for an element to contribute to the aspectual interpretation of a predicate, it must be within the domain of aspectual interpretation defined by AspP and everything contained by AspP. This implies that subjects and adjuncts, which are outside the domain of aspectual interpretation defined by AspP, cannot delimit the event of $\mathrm{V}$, in sharp contrast to complements, which are argued to be below AspP, occupying a position internal to VP and hence influencing the aspectual interpretation of the predicate; see the following tree diagram:

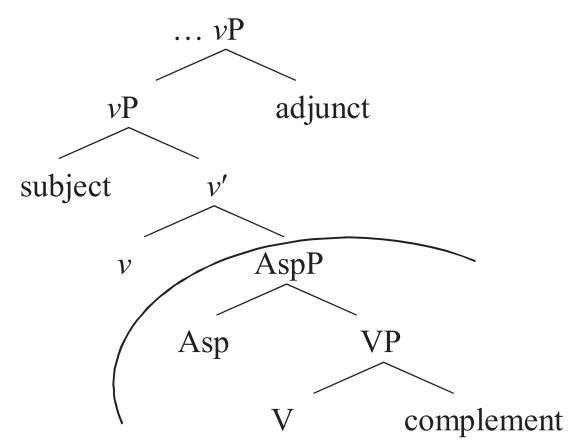

(adapted from MacDonald 2008: 58 ex. (74)) 
The starting point for the discussion in Travis (2010) is the hypothesis that, similarly to the movement of the subject DP from its merged position ([Spec, $v \mathrm{P}]$ ) to the specifier of a functional projection ([Spec, TP]), the object DP also undergoes movement from its merged position to the specifier of a functional projection. This means that there must be a functional head within the VP which is responsible for this latter movement and there seem to be morphological reasons to believe that there is an inflectional category within the VP, and that this non-lexical category is Aspect. Moreover, the specifier position of this latter functional projection ([Spec, AspP]) serves as the landing site for derived objects. More precisely, internal DP arguments affecting the aspectual interpretation of the predicate are merged in [Spec, VP] (logical object position) but they move to [Spec, AspP] (derived object position) if they induce a telic interpretation on it (see below). Similarly to MacDonald (2008), direct object themes are allowed to remain in [Spec, VP], in which case they do not measure out the event. In addition, it is not the case that all elements in the domain of inner aspect are part of the computation, but in order to be part of the computation, they must be part of this domain. The tree diagram in (19) shows these syntactic assumptions:

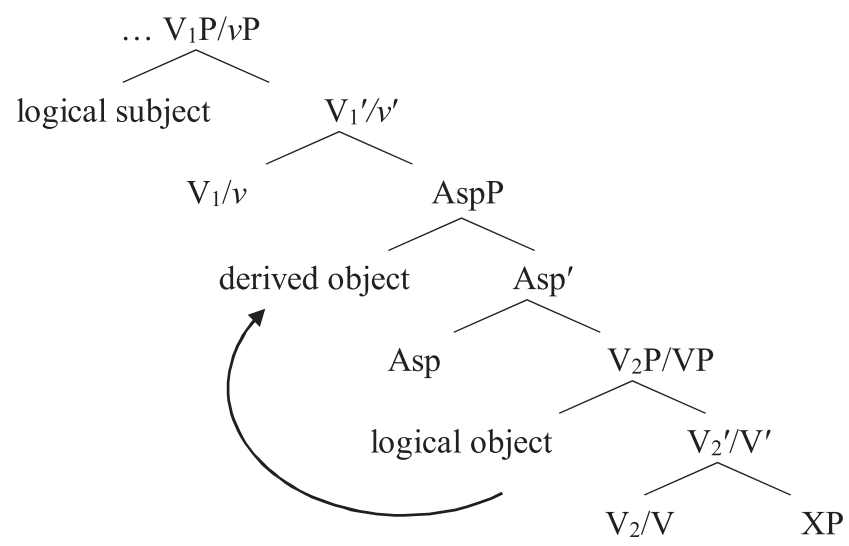

(adapted from Travis 2010: 34 ex. (29))

There are multiple positions in the articulated VP that have been claimed to figure into the calculation of inner aspectual interpretations. Travis (2010: 242, 244) argues for three positions where telicity can be marked and that languages can utilise in different ways:

(i) $\mathrm{X}$, the head of the complement of $\mathrm{V}_{2} / \mathrm{V}$ (where $\mathrm{X}$ is often realized as an $\mathrm{A}$ or a $\mathrm{P}$, and $\mathrm{XP}$ is a result predicate or a goal phrase $)^{4}$

[4] We assume that Hungarian result predicates like pirosra '(lit.) onto red' in pirosra festette a keritést 'painted the fence red' are base-generated as PP complements in VP. For more on PP resultatives in Hungarian, see Hegedûs (2013: 128-131). 
(ii) Asp (expressed by morphemes in Malagasy and Chinese) and the derived object position in [Spec, AspP], which is one possible landing site for DP movement within the VP; this specifier position is occupied by incremental themes

(iii) the upper $\mathrm{V}_{1} / v$ head, which is a light verb corresponding to CAUSE. This position is argued by Slabakova (1997) to be occupied by Slavic (more specifically, Bulgarian) preverbs

The different positions have important consequences with respect to the interpretation of the theme DP in the verbal predicate. For example, telicity-marking elements in $v$ (e.g. preverbs) in Bulgarian impose semantic restrictions on the theme DP such that it must be specific (or have a specific reading) by virtue of having this DP within their scope, i.e. in their c-command domain.

\section{THE PROPOSAL}

In this section of the paper we argue that telic interpretations become available in two different ways in Hungarian: (i) telicity may arise as an entailment due to an aspectual functional projection, AspP, sandwiched between $\mathrm{VP}$ and $v \mathrm{P}$ in the structure of the sentence, and (ii) it may also arise as an implicature in the case of a specific predicate class, the class of creation/consumption predicates. It is verbal particles like meg in VPs such as meg-eszik egy almát 'PRT-eat (up) an apple', result predicates like laposra '(lit.) onto flat' in resultative constructions such as laposra kalapálja a fémet 'hammer the metal flat' and non-subcategorized pseudo-objects like egyet 'one.ACC' in VPs such as fut egyet 'go for a run' that induce telicity in the [Spec, AspP] position by functioning as aspectual operators picking out maximal or contextually defined non-maximal subparts of the events denoted by their verbal predicates, thereby ensuring that the resulting verbal predicates have quantized reference. Telicity in this case cannot be cancelled, which is expected as it is 'the grammar, rather than the lexical semantics of any particular listeme' that forces 'the projection of telic structure' (Borer 2005: 153). On the other hand, created or consumed objects with quantized reference may also give rise to telic readings, but the predicates whose telicity is due to such objects can also easily receive atelic interpretations. It is also crucial to note that Hungarian objects with quantized reference in other verb classes do not have the ability to measure out events and thus such constituents do not give rise to telicity. Thus, Hungarian turns out to be different from languages like English, German, Dutch and Spanish, where bounded objects often have a measuring-out function in the environment of members of the class of creation/consumption verbs and those of other verb classes.

In this section we provide an analysis of entailed versus implied telicity by first discussing the syntax of verbal particles, result predicates and pseudo-objects in 
Sections 4.1 and 4.2, respectively, and then we devote Section 4.3 to the aspectual effects of created/consumed objects.

\subsection{Verbal particles and result predicates}

As noted earlier, Hungarian verbal particles and result predicates appear in the immediately preverbal position in neutral sentences and often have a telicizing function (Csirmaz 2008a; É. Kiss 2008a, b):

(a) Kati tíz perc alatt/*tíz percig meg-evett egy almát.

Kati ten minute under/ten minute.for PRT-ate an apple.ACC 'Kati ate (up) an apple in/*for ten minutes.'

(b) Kati két óra alatt/*két óráig

Kati two hour under/two hour.for

ropogósra sütött egy csirkét.

crispy.sub roasted a chicken.ACC

'Kati roasted a chicken crispy in/*for two hours.'

Verbal particles like meg (20a) and result predicates like ropogósra '(lit.) onto crispy' (20b) have been shown to encode an event-maximalizing operator $\left(M A X_{E}\right)$ (Filip \& Rothstein 2006), which is applied to a partially ordered set of events, from which they pick out the unique largest event at a given situation, thereby ensuring that the resulting predicates have quantized reference, and thus they are interpreted telically, as shown by the temporal adverbial test (see Kardos 2012, 2016). We argue that particles like meg exert their event-maximalizing function in their basegenerated [Spec, AspP] position by checking the $[+$ telic $]$ and $[+$ maximal $]$ features of the Asp head. As we will see in Section 4.2, meg-type telicity-marking verbal particles in examples like (20a) are different from pseudo-objects like egyet 'one. ACC' in VPs such as aludt egyet 'got some sleep', which we also assume to be basegenerated in [Spec, AspP], in that the latter are not associated with maximality, though they also give rise to verbal predicates with quantized reference and noncancellable telicity. The representation that we propose for sentences like Kati megevett egy almát 'Kati PRT-ate an apple' is given below: ${ }^{5}$

[5] As discussed in Section 2.2, Surányi (2009) assumes that there is one more step in the derivation of the neutral surface order: the particle undergoes movement to [Spec, TP] to check the EPP feature of $\mathrm{T}$, and the verb undergoes head-movement into T (via Asp and $v$, in our account). As these two (types of) movements do not play a role in the present analysis, they will not be discussed here, hence the functional domain above $v \mathrm{P}$ will not be illustrated. 
(21)

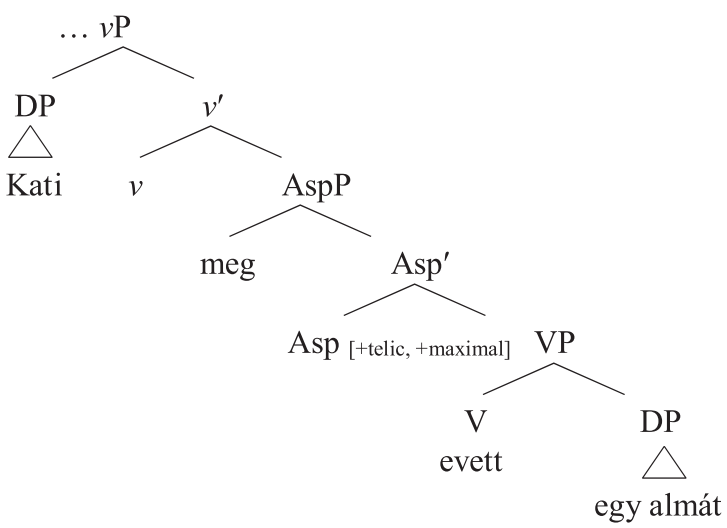

An important consequence of the event maximalizing element meg in [Spec, AspP] is that it imposes semantic constraints over the theme in its c-command domain such that it cannot be a bare plural associated with cumulative reference. Consider (22) below.

(22) (a) Kati meg-evett egy/három almát.

Kati PRT-ate an/three apple.ACC

'Kati ate an apple/three apples.'

(b) *Kati meg-evett almákat.

Kati PRT-ate apple.PL.ACC

That themes like almákat 'apples' cannot appear in the environment of event maximalizing elements follows from the fact that the event maximalizing operator $M A X_{E}$ encoded in the particle meg can only apply to events that are ordered with respect to the scalar arguments of their verbal predicates such that they function as a measuring device allowing the identification of the size of the denoted events. Since a measuring scale cannot be deduced with bare cumulative NPs, $M A X_{E}$ cannot apply (Filip 2008).

Cross-linguistically, it is not clear whether such an effect characterizes preverbs in languages such as Dutch and German. As also noted by Kardos (2019: 506-507 fn. 20), speaker judgements vary regarding the co-occurrence of particle verbs and themes with cumulative reference in these languages. In Travis (2010: 248 ex. (10)), the German sentence Ich habe zwei Stunden lang Weinflaschen ausgetrunken 'I drank up wine bottles for two hours' is shown to be grammatically somewhat questionable, whereas in Fleischhauer \& Czardybon (2016: 189 ex. (29b)) the sentence Der Mann hat Äpfel aufgegessen 'The man ate up apples' is marked as clearly ungrammatical. The latter example suggests that German particles like auf are similar to Hungarian verbal particles in that they also have an eventmaximalizing role. 
Another important consequence of event maximalization is that, in the presence of a verbal particle (23a) or a result phrase (23b), the attainment of a specific final state cannot be cancelled.

(a) \#János meg-ette az almát, János PRT-ate the apple.ACC de az nem fogyott el teljesen. but that not disappeared PRT completely

'János ate (up) the apple, but it did not disappear completely.'

(b) \#Kati ropogósra sütötte a csirkét,

Kati crispy.suB roasted the chicken.ACC de az nem lett ropogós.

but that not became crispy

'Kati roasted the chicken crispy, but it did not become crispy.'

The negation of the inference that the apple completely disappeared in (23a) and that the chicken became crispy in (23b) results in infelicity. This is evidence that the presence of the particle meg and that of the result predicate ropogósra '(lit.) onto crispy' ensures the attainment of the final states of being 'gone' and crispy, respectively.

Another important syntactic effect of particles like meg in the examples discussed so far is that they must appear with accusative-marked incremental themes. By contrast, in the absence of meg, the theme argument may also be assigned a case other than accusative. Compare and contrast the (a) and (b) examples in (24) and (25).

(24) (a) János tíz perc alatt/*tíz percig meg-evett egy almát. János ten minute under/ten minute.for PRT-ate an apple.ACC 'János ate (up) an apple in/*for ten minutes.'

(b) *János meg-evett egy almából. János PRT-ate an apple.ELA

(25) (a) János tíz perc alatt/tíz percig evett egy almát. János ten minute under/ten minute.for ate an apple.ACC 'János ate an apple in ten minutes/János spent ten minutes eating an apple.'

(b) János tíz percig/*tíz perc alatt evett egy almából. János ten minute.for/ten minute under ate an apple.ELA 'János spent ten minutes eating from an apple.'

As the examples show, the particle verb meg-evett 'PRT-ate' requires the accusative case marking - $t$ on the theme (24a) and rejects the constituent egy almából 'from an apple', which carries the elative case marking -ból (24b) and is associated with the meaning that the apple has been partially affected in the denoted eventuality. By contrast, the particleless verb evett 'ate' can occur either with a theme carrying accusative case, as in (25a), or one associated with elative case, as in (25b). We believe that these facts are compatible with the standard assumption that accusative 
case is assigned by little $v$ via Agree. When discussing data from Finnish, MacDonald argues that 'given the structural proximity of $v$ to Asp, there is no syntactic reason why the internal argument cannot Agree with Asp as well' (MacDonald 2008: 176). The representation that he gives for Finnish Maija luki kirjan 'Mary read a book (and finished it)' is as follows:

(26)

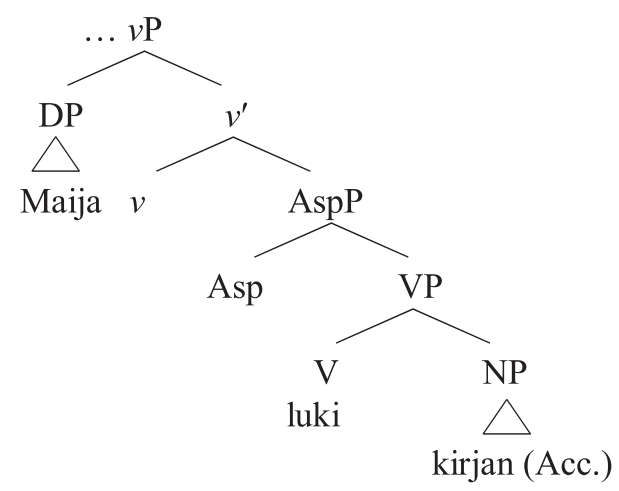

(MacDonald 2008: 175 ex. (18))

The syntactic representation that we propose for the Hungarian counterpart of the Finnish sentence above is given below, where, again, we represent the verb in its base-merged position:

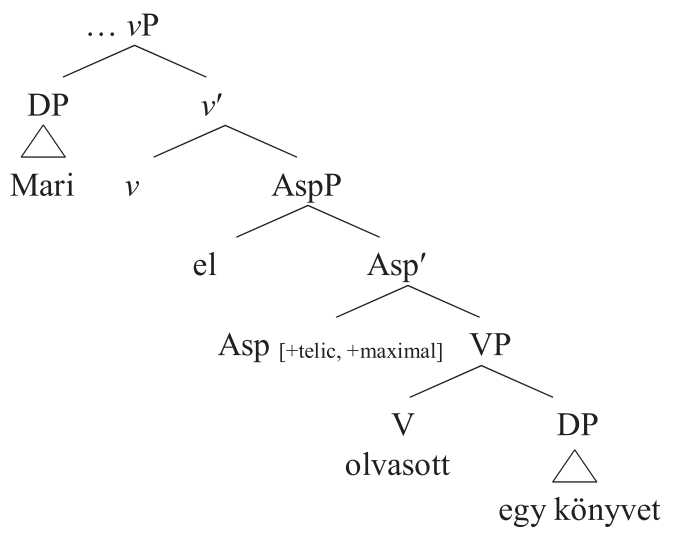

An important difference between Finnish and Hungarian when it comes to these structures is that whereas [Spec, AspP] is filled by an overt verbal particle in Hungarian (see (27)), there is no overt marking element in Asp or [Spec, AspP] in Finnish (see (26)). Likewise, the particle verb el-olvas 'PRT-read' in (28) is also incompatible with a theme argument that is assigned a case other than accusative. This is shown below. 
The particleless verb olvasott 'read', on the other hand, readily accepts objects with accusative case or elative case associated with a partitive reading, as illustrated in (29).
(a) Kati tíz perc
alatt/tíz percig
olvasott egy könyvet.
Kati ten minute
under/ten minute.for
read a
book.ACC
'Kati read a book in/for ten minutes.'
(b) Kati tíz percig/*tíz perc alatt olvasott egy könyvből. Kati ten minute.for/ten minute under read a book.ELA 'Kati read from a book for/*in ten minutes.'

Overall, then, we agree with MacDonald (2008: 171) in that case and aspect are independent syntactic categories, as evidenced by the fact that, for example, atelic stative structures also contain objects carrying accusative case (see the Hungarian examples in (31a) and (32a) below and the Finnish examples in MacDonald (2008: 175 exx. (17a) and (17b)). However, it appears that aspect and case are also related in a way that once AspP is projected, the morphosyntactic properties of the internal theme argument inside VP are constrained such that this argument must receive accusative case unless the internal argument is assigned nominative case in [Spec, $\mathrm{TP}]$ as the subject of the sentence in the case of unaccusatives. ${ }^{6}$ On the other hand, however, Hungarian objects alone do not contribute to the aspectual interpretation of the sentence in the absence of AspP regardless of the case assigned to them, as shown in (30). ${ }^{7}$ For more on this regarding other languages, see also Pereltsvaig $(2000)^{8}$ and Travis (2010).

[6] For more on the relationship between argument structural properties and event structural properties in Hungarian, see Kardos \& Pethő (2019).

[7] This generalization pertains to non-creation/non-consumption predicates. As we will show in Section 4.3, creation/consumption predicates can be interpreted telically with bounded, accusative objects, although an atelic reading is also allowed with such objects.

[8] Pereltsvaig (2000) argues for three different cases for objects across languages: Inherent Case, Structural Accusative Case and default objective Case. She focuses on Structural Accusative Case and default objective Case in her paper and claims that these cases are checked in different positions in the syntax, where the two positions are [Spec, AspP] and [Spec, VP], respectively. We assume that Hungarian objects are assigned case in their base position in the VP, whereas in languages like English accusative case is assigned to objects in the specifier of an aspectual functional projection above VP (see also Borer 2005). 
(b) Kati tíz percig/*tíz perc alatt hámozott a krumpliból. Kati ten minute.for/ten minute under peeled the potato.ELA 'Kati spent ten minutes peeling some of the potatoes.'

(c) Kati tíz perc alatt/*tíz percig meg-hámozta Kati ten minute under/ten minute.for PRT-peeled a krumplit.

the potato.ACC

'Kati peeled the potatoes in/*for ten minutes.'

As shown above, the particleless verb hámoz 'peel' in (30a) and (30b) heads an atelic predicate regardless of the type of case that is assigned to the internal theme argument, whereas the particle verb meg-hámoz 'PRT-peel' and the accusative object in (30c) form a telic predicate. By contrast, in English and other similar languages, an accusative DP that is also bounded is sufficient in the environment of the verb peel to express a telic situation.

Verbal particles like meg may also be attached to stative verbs like ért 'understand' and ismer 'know'. The particle verbs meg-ért 'PRT-understand' and megismer 'PRT-know' are no longer stative but they express change-of-state events.

(31) (a) János értette a feladatot.

János understood the task.ACC

'János understood the task.'

(b) János meg-értette a feladatot.

János PRT-understood the task.ACC

'János came to understand the task.'

(32) (a) Bálint ismerte a tanárt.

Bálint knew the teacher.ACC

'Bálint knew the teacher.'

(b) Bálint meg-ismerte a tanárt.

Bálint PRT-knew the teacher.ACC

'Bálint got to know the teacher.'

(Kardos \& Pethő 2019: 122 ex. (10))

The examples in (a) both describe stative situations, whereas the examples in (b) express telic changes of state. In (31b) the experiencer, János, ends up in the mental state of understanding the task, whereas in (32b) Bálint ends up in the final state of knowing the teacher. The telicity of the examples in (b) is due to the particle meg functioning as an event maximizer in [Spec, AspP], whereas the atelicity of the examples in (a) is attributed to the lack of AspP below $v \mathrm{P} .{ }^{9}$

[9] For a semantic analysis of verbal particles telicizing stative psych predicates, see Eszes (2008). 
Crucially, we side with Borer (2005) in claiming that 'atelicity is lack of telicity' (Borer 2005: 125), i.e. there is no specific atelic structure in the syntax: atelicity arises in the absence of AspP. Consider the representation of (31a) in (33), whereas (31b) is illustrated in (34).

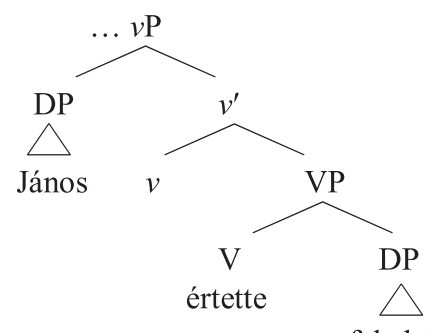

(34)

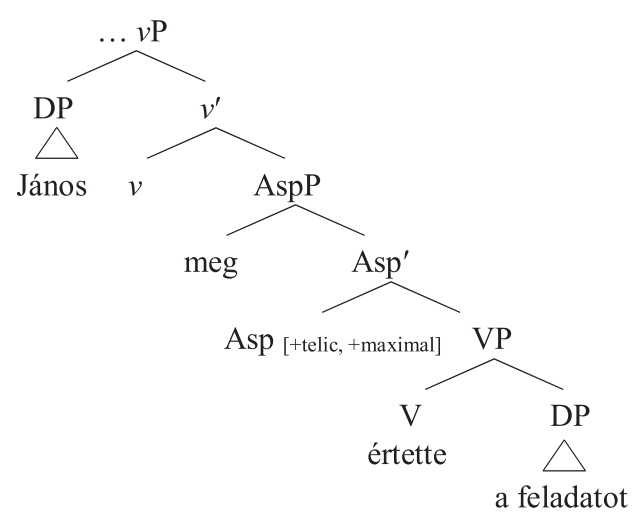

As far as resultative predicates are concerned, we first remark that they are frequently sublative case-marked, where the sublative suffix - $r a /$-re is primarily a directional case suffix expressing the meaning 'onto'. The RP is merged inside VP and moves to [Spec, Asp], where it exerts its telicizing function by virtue of checking the $[+$ telic] and [+maximal] features. As opposed to particles like meg, the RP has two functions: it turns the VP telic and it also specifies the result state. Sentence (20b), repeated as (35), is represented in (36). It must also be noted that the final word order characterizing this example is achieved by further movement of the $\mathrm{RP}$ and that of the verb to the specifier/head position of TP above $v \mathrm{P}$, see also fn. 5 above.

(35) Kati két óra alatt/*két óráig ropogósra sütött

Kati two hour under/two hour.for crispy.suB roasted egy csirkét.

a chicken.ACC

'Kati roasted a chicken crispy in/*for two hours.' 
(36)

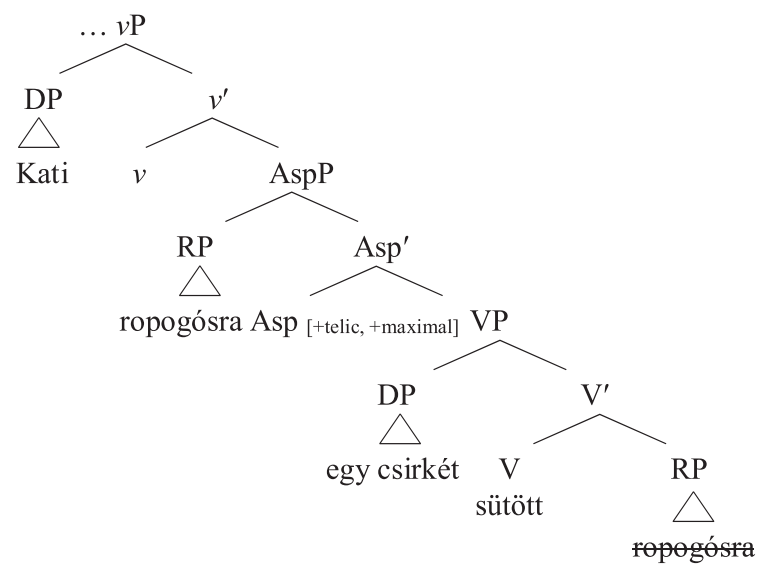

Crucially, RPs may co-occur with particles like $m e g$ as illustrated by the example in (37). This can be captured if we assume that particles like $m e g$ are merged in [Spec, AspP], whereas result predicates are generated as complements of $\mathrm{V}$ and stay in situ, as shown in (38) (again, further movements account for the final word order given in (37) below). ${ }^{10}$

Kati két óra alatt/*két oráig meg-sütött egy csirkét
Kati two hour under/two hour.for PRT-roasted a chicken.ACC
ropogósra.
crispy.suB
'Kati roasted a chicken crispy in/*for two hours.'

[10] As pointed out by Hegedús (2020), native speakers have different intuitions as to whether result predicates like that in (37) are contained in the same clause that also contains the verbal particle or they are just an afterthought, in which case they are outside the clause. In the latter case, there is an intonational break before the postverbal result phrase. If the particle and the result predicate co-occur in the same clause, we claim, along with Hegedús (2020: 328), that, given that they lexicalise information about the same endpoint, they do not challenge the constraint that an event can be delimited only once (see Tenny 1994). 
(38)

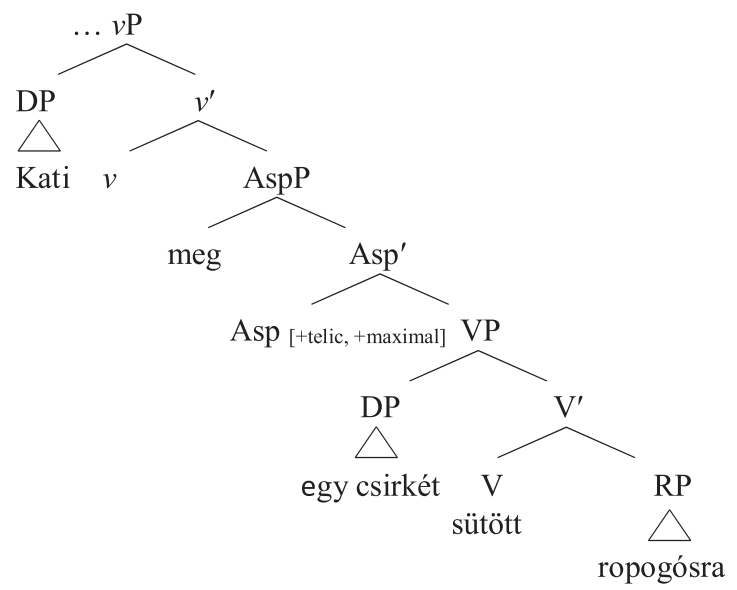

To summarize, in this section, we have shown that VPrts like meg and RPs like ropogósra '(lit.) onto crispy' are both capable of checking the [+telic] and [+maximal] features of the Asp head and thus they ensure that the predicates that contain them are telic. An important difference between them is that whereas the former is merged in [Spec, AspP], the latter is generated within the VP and obligatorily moves to [Spec, AspP] from its base position in the absence of a telicity-marking element in this specifier position.

In the next section, we turn to other aspectual marking elements which also give rise to telicity, but they do so without ensuring that the verbal predicate is associated with a maximal-event interpretation.

\subsection{Pseudo-objects}

POs like egyet 'one.ACC', egy jót 'one good.ACC', and egy nagyot 'one big.ACC', which typically accompany activity verbs (39), are accusative-marked constituents with no referential value. ${ }^{11}$

$\begin{array}{llllll}\text { Mari } & \text { aludt } & \text { egyet/sétált } & \text { egy } & \text { jót/ } & \text { futott } \\ \text { Mari } & \text { slept } & \text { one.ACC/walked } & \text { one } & \text { good.ACC } & \text { ran } \\ \text { egy } & \text { nagyot. } & & & & \\ \text { a } & \text { big.ACC } & & & & \end{array}$

'Mari got some sleep/took a good walk/went for a long run.'

[11] Semelfactives like kattan 'click' have also been shown to co-occur with egyet, as in A zár kattant egyet 'The lock clicked once' (Csirmaz 2008b), but we believe that this egyet behaves differently from the one we discuss in this paper (see also Piñón 2001). For instance, with semelfactives, egyet is a multiplicative expressing the number of times the eventuality denoted by the verb occurred, similarly to the multiplicative egyszer 'once'. By contrast, the sentence János sétált egyet 'János went for a walk' does not express that János walked once, but that he did some walking. For more details, see also Farkas (2021). 
They are also non-subcategorized and non-thematic objects, which do not denote an affected entity. ${ }^{12}$ They stand in contrast to subcategorized, referential and thematic internal arguments, as shown by the test of passivization below; see also Csirmaz (2008b), Farkas \& Kardos (2018) or Farkas (2019, 2021):
(a) János be-zárta az ajtót. $\mathrm{Az}$ ajtó be van zárva. János PRT-closed the door.ACC the door PRT is closed 'János closed the door. The door is closed.'
(b) János oda ütött egyet/ egy nagyot.
János there hit one.ACC one big.ACC
*Egy/egy nagy oda volt ütve.
one/one big there was hit
'János gave it a hit/a good hit. *A hit/a good hit was given (by János).'

The example in (40b) shows that the PO does not denote a referential entity, one that could be interpreted as the undergoer directly affected by the event of the verb, therefore it cannot appear in the derived subject position of passive structures, contra the object in (40a). For further syntactic tests that demonstrate the nonsubcategorized, non-referential and non-thematic quality of the PO, see Farkas (2021).

Drawing on Tenny's (1994) terminology, Csirmaz (2008b: 169) calls these POs situation delimiters, which turn atelic predicates into telic ones, as evidenced by the coordination test below:
(41) Juli délelôtt is és délután is pihent egyet. Juli morning too and afternoon too rested one.ACC 'Juli rested in the morning and she also rested in the afternoon.' (two eventualities)
*'Juli rested in the morning and in the afternoon too.' (single eventuality)

(Csirmaz 2008b: 179 ex. (50c))

This sentence can only be interpreted to describe two distinct resting eventualities, one in the morning and one in the afternoon. This kind of semantics is associated with telic event descriptions (Verkuyl 1993). Coordinated atelic event descriptions, on the other hand, can also be interpreted as expressing a single eventuality, as evidenced by (42), where the resting eventuality holds during both temporal intervals as a single eventuality.

[12] Other subclasses of pseudo-objects are reflexives such as magát 'himself.ACC' in a resultative construction like álomba sírta magát '(he) cried himself to sleep' as well as accusative-marked temporal (két órát 'two hour.ACC'), spatial (két métert 'two meter.ACC') or other measure phrases (kicsit 'little.ACC' or sokat 'a lot.ACC'); see Csirmaz (2008b) or Farkas (2021). The analysis proposed in this paper, however, does not extend to POs other than egyet 'one.ACC', egy jót 'one good.ACC' or egy nagyot 'one big.ACC'. 
(42) Juli délelôtt is és délután is pihent. Juli morning too and afternoon too rested 'Juli rested in the morning and in the afternoon, too.'

(Csirmaz 2008b: 179 ex. (50d))

Farkas \& Kardos (2018: 371) argue that these POs encode an aspectual operator that picks out a contextually specified non-maximal subpart of the events in the denotation of the verbal predicate.
Anna szárított egyet a haján,
Anna dried one.ACC the hair.Poss.suP
de még lehet rajta szárítani.
but still possible it.suP dry.INF
'Anna dried her hair a bit, but it could still use some drying.'

The non-maximality requirement is evidenced by the fact that the event expressed by the verbal predicate in the first clause can still be continued as in (43) or performed once again, as shown below:

(44) Anna szárított egyet a haján,
Anna dried one.ACC the hair.POss.suP
aztán késóbb megint szárított egyet rajta.
then later again dried one.ACC it.suP
'Anna dried her hair a bit and later she did it again.'

However, there is a minimum amount of hair-drying/sleeping/running etc. event that needs to occur for the truth of sentences containing egyet-type POs. This is illustrated below:

Context: John goes for a run in the forest but after ten meters he stops running and dies of a heart attack.
(a) János futott egyet, és hirtelen meghalt. FALSE János ran one.ACC and suddenly died 'János went for a run and suddenly died.'
(b) János futott, és hirtelen meghalt. János ran and suddenly died 'János ran and suddenly died.'

As shown by these examples, any amount of running will not satisfy the truth conditions of (45a). However, no such restriction is observable in (45b).

The fact that maximality is not associated with egyet-VPs is also evidenced by their incompatibility with adverbials such as teljesen 'completely', egészen 'completely' or maximálisan 'maximally' (see also Farkas \& Kardos 2018: 372). Consider the example below: 
(46)

$\begin{array}{lll}\text { \#Anna teljesen/egészen/maximálisan } & \text { szárított } \\ \text { Anna completely/completely/maximally } & \text { dried } \\ \text { egyet a haján. } & \\ \text { one.ACC the hair.POSs.SUP } & \end{array}$

As expected, the verbal predicate száritott egyet a haján 'dried her hair a bit' may also appear in a sentence where the attainment of a maximal endpoint corresponding to the state of complete dryness is cancelled. ${ }^{13}$ This is shown below.

$\begin{array}{lllll}\text { Anna } & \text { szárított } & \text { egyet } & \text { a haján, } \\ \text { Anna dried } & \text { one.ACC } & \text { the hair.POss.sup } \\ \text { de az nem } & \text { lett } & \text { teljesen } & \text { száraz. } \\ \text { but that not } & \text { became } & \text { completely } & \text { dry }\end{array}$

'Anna dried her hair a bit, but it did not become completely dry.'

In addition, in line with the non-maximality requirement, egyet-VPs are not associated with a prominent end result state or location, unlike verbal particles or result predicates. Thus, clauses containing a $\mathrm{PO}$ are compatible with continuations that express that no specific endpoint has been reached at the termination of the event described by the verbal predicate.
A diák futott egyet anélkül, hogy elért volna valahova. the student ran one.ACC without that reached would somewhere 'The student went for a run without getting anywhere.'

Furthermore, predicates encoding an open scale can appear with egyet 'one.ACC' (49a), but those encoding a closed scale - where maximality is encoded in the verb cannot (49b); see also Farkas \& Kardos (2018: 371):
(a) A munkások
szélesítettek
egyet
a hídon.
the workers widened
one.ACC the bridge.suP
'The workers made the bridge a bit wider.'
$\begin{array}{cllll}\text { (b) *A takarítónó } & \text { ürített } & \text { egyet } & \text { a } & \text { szobán. } \\ \text { the cleaning.lady } & \text { emptied } & \text { one.ACC } & \text { the } & \text { room.suP }\end{array}$

Then, egyet 'one.ACC' cannot appear with achievements, which are maximally delimited; see also Csirmaz (2008b: 179):
*János
érkezett
egyet.
János
arrived
one.ACC

[13] Recall from Section 4.1 that with particle verbs like meg-evett 'PRT-ate' the attainment of a final state cannot be cancelled (see example (23a)). This also characterizes the predicate megszárította a haját 'PRT-dried her hair', as shown by the semantic anomaly in \#Anna meg-szárította a haját, de az nem lett teljesen száraz 'Anna dried her hair, but it did not become completely dry'. While for some speakers this sentence may not be fully anomalous, as pointed out by a referee, we believe that there is a clear difference between the acceptability of (47) and that of the sentence above in this footnote. The example in (47) is completely natural, while the sentence containing the predicate meg-száritotta a haját 'PRT-dried her hair' is at least slightly awkward. 
As will be further illustrated in Section 5, verbs like érkezik 'arrive' are also incompatible with POs since it is not possible for the latter to be assigned accusative case in an unaccusative structure.

Finally, predicates containing POs have a simple event structure. This is evidenced by their non-ambiguous counterfactual reading with the adverb majdnem 'almost' (see also Farkas \& Kardos 2019b: 301), which makes these structures similar to what Piñón (2008: 91-92) refers to as weak accomplishments.

(51) Ma reggel Mari majdnem futott egyet. today morning Mari almost ran one.ACC 'This morning, Mari almost went for a run.'

In the case of this sentence the only reading available is the counterfactual one, in which the adverb majdnem 'almost' has wide scope and modifies the entire event, so the event almost begins (i.e. 'this morning Mari almost went for a run but crucially she did not'). The incompletive interpretation, in which majdnem 'almost' has narrow scope and modifies the end of the event, so the event begins and almost ends, is not available.

Overall, then, it is clear that egyet-type pseudo-objects are responsible for nonmaximal event delimitation and in this respect they contrast with verbal particles and result predicates, which are associated with a maximal-event interpretation, as discussed in Section 4.1.

With respect to their syntax, two properties need to be taken into consideration: (i) POs differ from subcategorized, thematic and referential internal arguments, which are merged inside the VP; and (ii) they are associated with telicity and non-maximality. We argue that they are merged in the specifier of AspP, where they check the $[+$ telic] and [-maximal] features of the head. The tree diagram that we propose for a sentence like Marifutott egyet 'Mari went for a run' is given below:

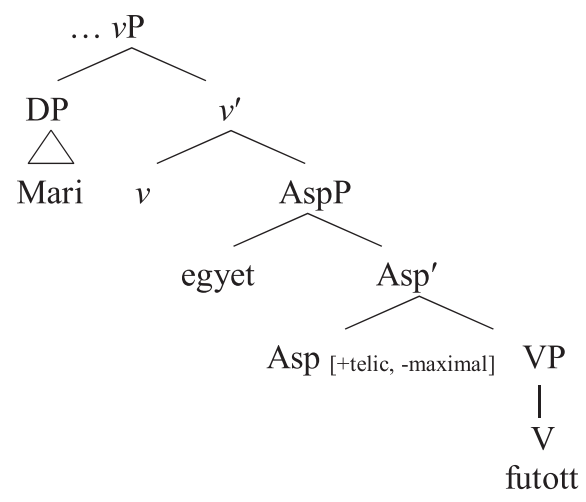


In addition, as egyet 'one.ACC' does not undergo movement to a position inside a higher (functional) phrase but the verb undergoes head movement (at least) from $\mathrm{V}$ to Asp and then to $v$, at the end of the derivation the postverbal position of egyet is ensured. ${ }^{14}$

In sum, in this section we have taken a close look at the properties of the Hungarian PO egyet 'one.ACC', and some other POs with similar aspectual features. We have shown how these pseudo-objects are different from canonical, referential objects in their grammatical behaviour. In the next section, we turn to a subset of referential objects, created/consumed objects, which can also make verbal predicates telic given their specific grammatical properties.

\subsection{Created/consumed objects}

CCOs in Hungarian, similarly to English, German, Dutch, Italian and Spanish, can measure out events (Tenny 1994) when associated with quantized reference (É. Kiss 2005, 2008a; Csirmaz 2008a; Piñón 2008), as shown in (53):
(a) Mari tíz perc alatt ivott egy limonádét.
Mari ten minute under drank a lemonade.ACC
'Mari drank a lemonade in ten minutes.'
(b) János egy év alatt épített egy házat. János one year under built a house.ACC 'János built a house in a year.'

Kardos (2012, 2019) argues, assuming Beavers's (2012) figure-path relations model, which is built on Krifka's (1998) mereological analysis of telicity, that it is the unique homomorphic relation obtaining between the part structure of the scalar argument of creation/consumption predicates and that of the theme that gives rise to the aspectual effects characterizing these predicates. On this analysis, verbs like Hungarian eszik 'eat' and English eat are four-place predicates expressing a relation between a scalar argument $s$, a causer $y$, a figure $x$, and an event $e$. Scales are assumed to have a mereological part structure comprising atomic subparts, which are totally ordered states $\left(s_{0}, s_{l}\right)$ corresponding to states of affairs in which the referent of the theme has been consumed bite by bite. Consumption scales $S_{\text {cons }}$ are characterized as follows:

[14] We must also note that speaker judgements vary with respect to the position of the PO egyet 'one. ACC' in the Hungarian sentence. For example, speakers of the székely dialect of Hungarian spoken in Transylvania tend to prefer the word order PO-V, as in egyet futott 'went for a run', whereas speakers within Hungary often have a preference for the word order variant V-PO, as in futott egyet 'went for a run'. In addition, it is also known that whereas in the Early Modern Hungarian texts written before 1850 egyet 'one.ACC' precedes the activity verb, in the Early Modern and Modern texts written between 1850 and 1950 the same PO appears both in the preverbal and in the postverbal position. As a result of diachronic change, the PO is almost exclusively postverbal in the texts belonging to the second half of the 20th century (for more details, see Farkas 2020b). 


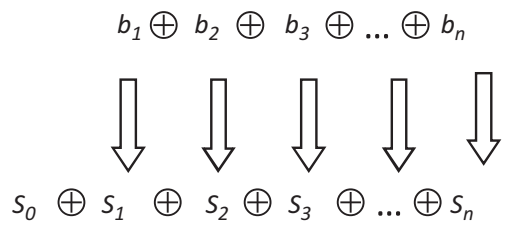

Figure 1

The part structure of the consumption scale as determined by the part structure of the theme.

(54) (a) Atomic elements in $S_{\text {cons }}$ are $s_{i}$, where $i \geq 0$.

(b) For any $s, s_{i}, s_{j} \in S_{\text {cons }}$, where $s_{i}$ and $s_{j}$ are atomic, if $s_{i}$ and $s_{j}$ are proper parts of $s, s_{i}<<s_{j}$ (i.e. $s_{i}$, the state of having consumed as many bites as $i$ is ordered before $s_{j}$, the state of having consumed $j$ bites) iff $i<j$.

(Kardos 2019: 512 ex. (34))

The unique homomorphic relationship that obtains between scales and themes in this predicate class is shown in Figure 1, taken from Kardos (2019: 512), where $b_{1}$, $b_{2}$ correspond to the bites the theme can be divided into in an eating event:

On this analysis, consumption (and creation) verbs lexically encode a homomorphic relation between the scale and the theme, which ensures that the initial subevent of the eating event corresponds to a state of affairs wherein not a single bite of the referent of the theme has been consumed and the final subevent corresponds to a state of affairs wherein the theme has completely disappeared. Telicity obtains if the final subpart of the scale can be determined, as in the case of themes having quantized reference (ibid.). ${ }^{15}$

In the case of non-creation/non-consumption predicates, where the structure of the scale encoded in the head verb is independent of the theme, as in (55), Hungarian predicates containing a quantized theme and a base verb are obligatorily atelic. ${ }^{16}$

(55) (a) A pincér tíz percig/??tíz perc alatt melegített egy the waiter ten minute.for/ten minute under warmed a tányért.

plate.ACC

'The waiter warmed a plate for/??in ten minutes.'

[15] A referee remarks that predicates like sütöttem süteményeket 'I baked cookies' can also be telic despite the fact that the theme does not have quantized reference (see also É. Kiss 2008b: 143). This example is marginally acceptable to us with the adverbial egy fél óra alatt 'in half an hour' in an outof-the-blue context. We think that this predicate expresses an atelic activity, but in a context where the agent does this activity habitually, a telic interpretation may be available (for some speakers) in the presence of an alatt-adverbial, but, crucially, not without it. For more on similar effects in English, see Dowty's (1979: 61) discussion of the example John swam in an hour.

[16] In English, however, the quantized nature of the theme in predicates like widen the road and warm a plate is sufficient for telicity to obtain given specific contextual conditions (see Hay et al. 1999). 
(b) Mari tíz percig/*tíz perc alatt takarított egy asztalt. Mari ten minute.for/ten minute under wiped a table.ACC 'Mari wiped a table for/*in ten minutes.'

As expected based on the discussion in Subsection 4.1, the telicity of these predicates is ensured by constituents external to the verb and the thematic object; it is either a verbal particle, a result predicate or a pseudo-object that is directly responsible for non-cancellable telic interpretations in the class of non-creation/ non-consumption predicates. The difference in the semantics of the predicates representing the two predicate classes is also captured in the logical representations below the examples in (56) and (57), where the function $f$ ' is responsible for picking out the final subpart of consumption scales in the presence of quantized themes. ${ }^{17}$
(a) Peter ate two pears.
(specific goal point $\rightarrow$ telic predicate)
$\exists s \exists x \exists e\left[e a t^{\prime}(\operatorname{peter}, x, s, e) \wedge \operatorname{SOURCE}\left(s_{O}, s, e\right) \wedge \operatorname{GOAL}\left(f^{\prime}(x), s, e\right) \wedge\right.$
$\left.2 \operatorname{pears}^{\prime}(x)\right]$

(b) Peter ate pears. $\quad$ (non-specific goal point $\rightarrow$ atelic predicate)

$$
\exists s \exists x \exists g \exists e\left[e^{2 a t}(\mathbf{p e t e r}, x, s, e) \wedge G O A L(g, s, e) \wedge \operatorname{pears}^{\prime}(x)\right]
$$

(57) (a) The soup warmed. (telic) (specific goal point $\rightarrow$ telic predicate)

$$
\exists s \exists e\left[\text { warm' }^{\prime}(\mathbf{s o u p}, s, e) \wedge G O A L(\text { warm }, s, e)\right]
$$

(b) The soup warmed. (atelic) (non-specific goal point $\rightarrow$ atelic predicate) $\exists s \exists g \exists e\left[w^{\prime} \operatorname{rrm}^{\prime}(\mathbf{s o u p}, s, e) \wedge G O A L(g, s, e)\right]$

(Kardos 2019: 515 exx. (36)-(37))

Crucially, however, Hungarian objects like egy limonádét 'a lemonade.ACC' and egy házat 'a house.ACC' can just as easily give rise to atelic interpretations with ivott 'drank' and épített 'built', respectively, as shown in (58) below. ${ }^{18}$
(a) Mari tíz percig
Mari ten minute.for drank a lemonade.ACC
'Mari drank/was drinking a lemonade for ten minutes.'
(b) János egy évig épített egy házat.
János one year.for built a house.ACC
'János built/was building a house for a year.'

Here we would like to reiterate Borer's (2005: 153-154) idea that the projection of some grammatical structure (due to, for example, a DegP headed by completely in straighten the rope completely) is what ensures the impossibility of cancelling telicity. If our hypothesis that no quantity structure (using Borer's terminology) is

[17] Boldface indicates constants in the representations and $g$ is the goal point associated with scale $s$.

[18] There is now a good amount of literature on variable telicity effects in different predicate classes such as accomplishments like eat the soup, activities like run, and degree achievements like warm. See Section 2.1 for more on this. 
associated with Hungarian predicates like those in (58) is correct, it is perhaps to be expected that telicity in such cases is cancellable.

Once the particle meg appears in the predicate, however, which, as we argue above, occupies [Spec, AspP], telicity is not cancellable. The representation of (59) is given in (60).
Mari tíz perc alatt/*tíz percig meg-ivott
Mari ten minute under/ten minute.for PRT-drank
egy limonádét.
a lemonade.ACC
'Mari drank a lemonade in/*for ten minutes.'

(60)

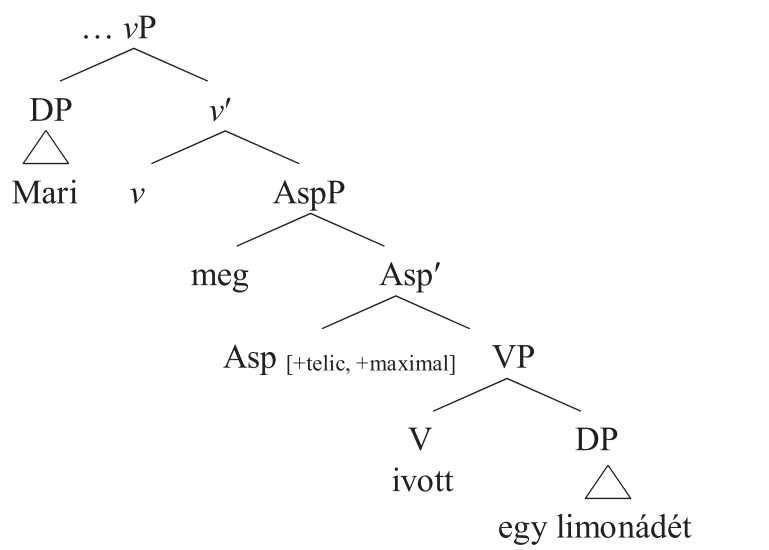

In light of this, a question arises regarding the English data: Why is it that English creation/consumption predicates like drink a lemonade and build a house, which contain a theme with quantized reference and no verbal particle, are preferably telic? Borer's (2005) answer to this question is that such predicates are associated with a quantity structure and thus they are telic, whereas according to Travis's (2010: 261-262) analysis of these and other similar data, the telicity of these predicates is due to a zero telicity marker in the complement of the lower VP. However, this position can also be filled, as in the case of resultative constructions like that in (61).

(61) The children hammered the nail flat (in/*for three minutes).

(Travis 2010: 262 ex. (43b))

In Hungarian, by contrast, we argue that non-cancellable telicity is due to verbal particles like meg and result predicates, among other aspectual markers, which exert their telicity-marking function in a position higher than VP (i.e., in [Spec, AspP]).

Finally, it is important to note that Hungarian predicates whose telicity is an implicature, as shown above, are associated with a simple event structure. This is 
evidenced by their non-ambiguous counterfactual reading when they appear with the adverb majdnem 'almost' (Piñón 2008: 92).

(62) Péter majdnem evett egy szendvicset.

Péter almost ate a sandwich.ACC

'Péter almost ate a sandwich.'

The example above can only receive a single reading in which the adverb majdnem 'almost' has wide scope and modifies the whole event such that Péter did not begin eating a sandwich. The incompletive reading such that Péter did not finish eating a sandwich is not readily available. Once the verbal particle meg appears in the sentence, however, both readings become available (Piñón 2008: 93).

$$
\begin{array}{lll}
\text { Péter majdnem meg-evett egy } & \text { szendvicset. } \\
\text { Péter almost } & \text { PRT-ate a } & \text { sandwich.ACC } \\
\text { 'Péter almost ate (up) a sandwich.' }
\end{array}
$$

The predicate in (63) can either mean that Péter did not even begin eating a sandwich (counterfactual interpretation) or that he began eating a sandwich but did not finish it (incompletive interpretation). Likewise, the predicate majdnem fel-épitett egy házat 'almost PRT-built a house' is ambiguous, as illustrated by the examples below:

(a) Péter majdnem fel-épített egy házat, de végül
Péter almost PRT-built a house.ACC but eventually
nem kezdett hozzá, mert nem kapott hitelt.
not began PRT because not received loan.ACC
'Péter almost built a house but he failed to begin building it as he had not received a loan.'

(b) Péter majdnem fel-épített egy házat, de végül Péter almost PRT-built a house.ACC but eventually nem fejezte be mert nem kapott hitelt. not finished PRT because not received loan.ACC 'Péter almost built a house but he failed to finish building it as he had not received a loan.'

As shown above, majdnem fel-épitett egy házat 'almost PRT-built a house' is compatible with a scenario in which Péter did not even begin building a house and also with one in which he began building a house but failed to finish it. If we take event structural facts to be reflected in the syntax, as argued by Borer (2005) and also discussed in Section 4.1, the data in (64) can be regarded as evidence for a more complex syntactic structure associated with these predicates. However, in light of this discussion and that of egyet-type marking elements in Section 4.2 (see example (51)) we conclude that both telicity and event maximality seem to be necessary for a complex-event interpretation. 


\section{Some CO-OCCURRENCE RESTRICTIONS IN THE EVENT DOMAIN}

After giving an analysis of three classes of telicity marking strategies in Hungarian, in this section of the paper we discuss two consequences of the analysis by focusing on various co-occurrence restrictions pertaining to inner aspectual marking elements.

The first prediction of our analysis is that VPrts like meg and $e l$ and POs cannot co-occur in the same verbal predicate because they compete for the same position in the Hungarian sentence, with [Spec, AspP] being the merged position of these elements. This is confirmed by the ungrammaticality of the following examples (see also Csirmaz 2008b), with (65a) represented in (66).

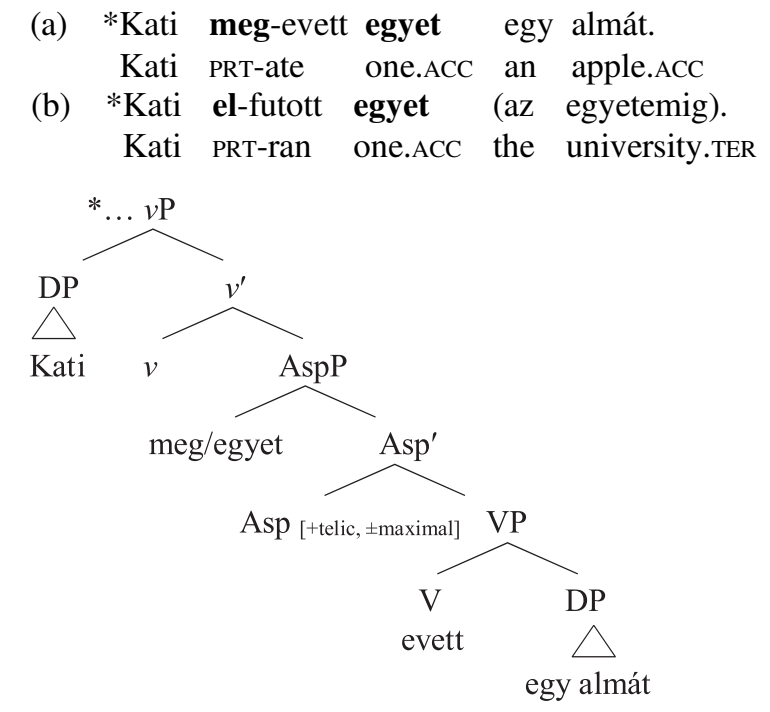

Resultative predicates like that in (67) are also expected to be ungrammatical with egyet 'one.ACC' in them, since although result predicates are assumed to be merged as complements in VP, whereas POs are merged in [Spec, AspP], they are associated with the features [+maximal] and [-maximal], respectively. This causes a maximality conflict in the sentence. ${ }^{19}$
*A hó
pocsolyává olvadt
egyet.
the snow
puddle.TRA melted
one.ACC

Crucially, the complementary distribution of POs and VPrts only applies to separable VPrts which are associated with the $[+$ telic $]$ and $[+$ maximal $]$ features.

[19] The structure in (67) is also ruled out since the PO cannot be assigned accusative case in the environment of the unaccusative verb olvad 'melt', as evidenced by the ungrammaticality of the string *A hó olvadt egyet '(lit.) The snow melted one.ACC'. 
As shown in Hegedús \& Dékány (2017) and also discussed earlier in our paper, particle verbs may also be associated with an inseparable particle, where the particle appears in the immediately preverbal position in both neutral (68a) and non-neutral (68b) sentences (e.g. declaratives with negation).
(a) A diák felvételizett a Bölcsészettudományi Karra. the student took.an.exam the Humanities Faculty.sub 'The student took an entrance exam at the Faculty of Humanities.'
(b) A diák nem felvételizett/*nem vételizett fel the student not took.an.exam/not took.an.exam PRT a Bölcsészettudományi Karra. the Humanities Faculty.sub
'The student did not take an entrance exam at the Faculty of Humanities.'

If the assumption of Hegedús \& Dékány (2017) that inseparable particles are merged low is correct and our claim that POs are merged in [Spec, AspP] is also correct, inseparable particle verbs should be compatible with POs. This is borne out in (69):

(69) A diák felvételizett egyet a Bölcsészettudományi
the student took.an.exam one.ACC the Humanities
Karra.
Faculty.suB
'The student took an entrance exam at the Faculty of Humanities.'

We also believe that there is evidence for particles like szét to be merged in [Spec, AspP] when they are attached to inseparable particle verbs like felvételizik 'take an entrance exam' as the particle szét turns the base predicate, which is atelic, into a telic one. ${ }^{20}$

(70) (a) A diák egy óráig/*egy óra alatt felvételizett. the student one hour.for/one hour under took.an.exam 'The student spent an hour taking an entrance exam.'

(b) A diák egy óra alatt/*egy óráig the student one hour under/one hour.for szét-felvételizte az agyát. PRT-took.an.exam the brain.POSS.ACC 'The student got exhausted with taking an entrance exam in/*for an hour.'

(adapted from Hegedűs \& Dékány 2017: 75 ex. (20b))

[20] Although this process is not common in Hungarian, as pointed out by a referee, there are some more examples illustrating the same phenomenon in Hegedűs \& Dékány (2017). 
Moreover, POs can also co-occur with separable particles that do not have a telicizing function, as shown below. ${ }^{21}$
A bácsi
el-töprengett/el-mélázott
egyet
the old.man
PRT-pondered/PRT-mused
one.ACC
a gazdasági válságon.
the economic crisis.suP
'The old man mulled over the economic crisis.'

(adapted from Csirmaz 2008b: 185 ex. (66a))

Contra Csirmaz (2008b: 185), who rules out the above sentence and argues that POs can never appear with particles, independently of the aspectual contribution of the latter, we consider such sentences to be fully acceptable. As in such and similar cases the particle does not make the predicate telic, it is arguably located in a different position than [Spec, AspP] and the PO enters the syntax in [Spec, AspP].

Another significant co-occurrence restriction is one pertaining to POs and accusative DP arguments, and is illustrated below:
(a) *János evett egyet egy levest. János ate one.ACC a soup.ACC
(b) *Józsi igazított egyet egy nyakkendőt. Józsi fixed one.ACC a tie.ACC

What is puzzling about the examples above is that although POs and thematic objects are argued in our analysis to occupy different positions in the syntax (and hence they do not compete for the same syntactic position, as shown below), the examples in (72a) and (72b) are ungrammatical.

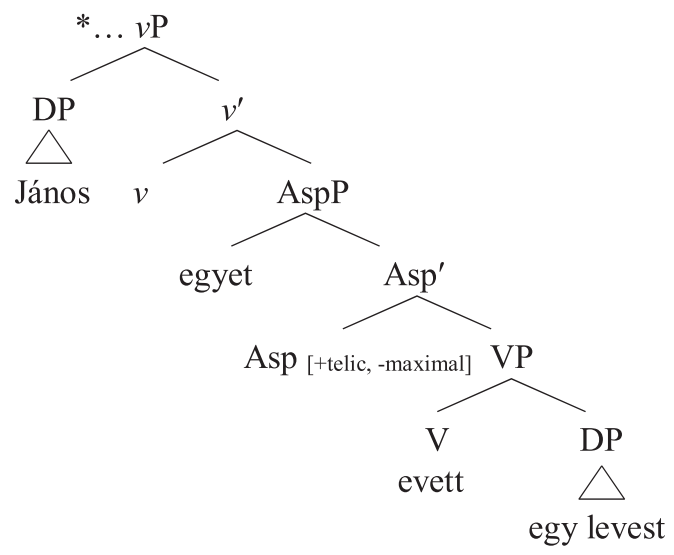

[21] We thank György Rákosi for drawing our attention to this example. 
We believe that this has to do with how (accusative) case assignment and inner aspect interact in Hungarian. On the one hand, we have already noted in Section 4.1 that in the presence of event-maximizing verbal particles like meg, merged in [Spec, AspP], the assignment of accusative case to the internal theme argument becomes obligatory; see the following examples, repeated from Section 4.1:

(74) János meg-evett egy almát/*egy almából.

János PRT-ate an apple.ACC/an apple.ELA

'János ate (up) an apple/*from an apple.'

Conversely, in the absence of an event-maximizing verbal particle like meg, the theme may receive accusative case (e.g. egy almát 'an apple.ACC') or elative case (e.g. egy almából 'an apple.ELA').

(75) János evett egy almát/egy almából.

János ate an apple.ACC/an apple.ELA

'János ate an apple/from an apple.'

On the other hand, the incompatibility of POs and accusative theme DPs is assumed to be a consequence of the theme DP's inability to get accusative case from $v$ since egyet 'one.ACC' intervenes between $v$ and the theme DP. ${ }^{22}$ By contrast, nonaccusative theme DPs can appear in the presence of egyet-POs, as evidenced by the following examples:

(76) (a) Kati evett egyet a levesból.

Kati ate one.ACC the soup.ELA

'Kate ate some soup.'

(b) Józsi igazított egyet egy nyakkendőn.

Józsi fixed one.ACC a tie.suP

'Józsi fixed a tie a little.'

Finally, we find it important to reiterate that there is no one-to-one correspondence between case and inner aspect in Hungarian: accusative case and the boundedness of the theme alone will not give rise to telicity in the case of the majority of verbal predicates, contra what we often see in English and other similar languages (see Section 4.1). Telicity is guaranteed in the presence of aspectual markers contributing to the aspectual interpretation of the sentence once they merge in the syntax due to the presence of AspP in the event domain.

\section{Conclusion}

In this paper we have analysed the syntax of inner aspect in Hungarian by attributing the event aspectual interpretations associated with three classes of telicity-marking

[22] We thank a referee for pointing this out to us. 
elements to the syntactic configuration characterizing these elements. We have proposed, building on much recent literature on inner aspectual markers in Hungarian, that, (i) similarly to many other languages, Hungarian has a $v \mathrm{P}$-internal aspectual projection, AspP, which is directly responsible for non-cancellable telicity effects induced by verbal particles, result predicates and non-subcategorized pseudo-objects, and (ii) telicity may also obtain in the presence of bounded themes in the class of creation/consumption predicates. As opposed to the previous case, where telicity is an entailment, telicity in this latter case is an implicature and so it is cancellable. Our analysis has also allowed us to make some predictions about the co-occurrence restrictions pertaining to POs and verbal particles as well as result predicates, and we have also made some important observations about how inner aspect and case interact in Hungarian.

\section{REFERENCES}

Beavers, John. 2012. Lexical aspect and multiple incremental themes. In Violeta Demonte \& Louise McNally (eds.), Telicity and change of state in natural language: Implications for event structure, 23-59. Oxford: Oxford University Press.

Borer, Hagit. 2005. Structuring sense, vol. 2: The normal course of events. Oxford: Oxford University Press.

Csirmaz, Anikó. 2008a. Particles and a two component theory of aspect. In É. Kiss (ed.), 107-128.

Csirmaz, Anikó. 2008b. Accusative case and aspect. In É. Kiss (ed.), 159-200.

De Swart, Henriëtte. 2012. Verbal aspect. In Robert I. Binnick (ed.), The Oxford handbook of tense and aspect, 752-780. Oxford: Oxford University Press.

Dowty, David. 1979. Word meaning and Montague Grammar. Dordrecht: Reidel.

É. Kiss, Katalin. 2002. The syntax of Hungarian. Cambridge: Cambridge University Press.

É. Kiss, Katalin. 2004. Egy igekötô elmélet vázlata [An outline of a theory of verbal particles]. Magyar Nyelv C.1, 15-42.

É. Kiss, Katalin. 2005. First steps towards a theory of the verbal particle. In Christopher Piñón \& Péter Siptár (eds.), Approaches to Hungarian, vol. 9: Papers from the Düsseldorf Conference, 57-88. Budapest: Akadémiai Kiadó.

É. Kiss, Katalin (ed.). 2008. Event structure and the left periphery. Dordrecht: Springer.

É. Kiss, Katalin. 2008a. The function and the syntax of the verbal particle. In É. Kiss (ed.), 17-55.

É. Kiss, Katalin. 2008b. From the grammaticalization of viewpoint aspect to the grammaticalization of situation aspect. In É. Kiss (ed.), 129-157.

Eszes, Boldizsár. 2008. Verbal particles telicizing stative psych verbs. In É. Kiss (ed.), 57-73.

Farkas, Imola-Ágnes. 2019. Sóhajtott egyet, mélyet, hangosat: a magyar áltárgyak mint aspektuális belső tárgyak [He sighed a deep, loud sigh: Hungarian pseudo-objects are aspectual cognate objects]. Nyelvtudományi Közlemények 115, 173-198.

Farkas, Imola-Ágnes. 2020a. Atelic unaccusative verbs and cognate objects in Hungarian. Argumentum 16, 95-114.

Farkas, Imola-Ágnes. 2020b. Az egyet áltárgy diakróniájáról [On the diachrony of the pseudo-object egyet 'one.AcC']. In Katalin Balogné Bérces, Attila Hegedűs \& Lilla Pintér (eds.), Nyelvelmélet és diakrónia 4 [Linguistic theory and diachrony 4], 87-113. Budapest \& Piliscsaba: PPKE BTK.

Farkas, Imola-Ágnes. 2021. Aspectual cognate objects in Hungarian. Folia Linguistica 55.2, 389-432.

Farkas, Imola-Ágnes \& Éva Kardos. 2018. Non-maximal event delimitation in Hungarian. Argumentum $14,368-382$.

Farkas, Imola-Ágnes \& Éva Kardos. 2019a. A végpontosság mint szituációs aspektuális jegy jelölése a magyar nyelvben. 1. rész [Marking telicity as an inner aspectual property in Hungarian Part 1]. Magyar Nyelv 115.2, 176-185.

Farkas, Imola-Ágnes \& Éva Kardos. 2019b. A végpontosság mint szituációs aspektuális jegy jelölése a magyar nyelvben. 2. rész [Marking telicity as an inner aspectual property in Hungarian Part 2]. Magyar Nyelv 115.3, 298-308. 
Filip, Hana. 2008. Events and maximalization. In Susan Rothstein (ed.), Theoretical and crosslinguistic approaches to the semantics of aspect, 217-256. Amsterdam: John Benjamins.

Filip, Hana \& Susan Rothstein. 2006. Telicity as a semantic parameter. In James Lavine, Steven Franks, Hana Filip \& Mila Tasseva-Kurktchieva (eds.), Formal approaches to Slavic linguistics (FASL) 14, 139-156. Ann Arbor, MI: Michigan Slavic Publications.

Fleischhauer, Jens \& Adrian Czardybon. 2016. The role of verbal prefixes and particles in aspectual composition. Studies in Language 40.1, 176-203.

Hale, Kenneth \& Samuel Jay Keyser. 2002. Prolegomenon to a theory of argument structure. Cambridge, MA: MIT Press.

Hay, Jennifer, Christopher Kennedy \& Beth Levin. 1999. Scalar structure underlies telicity in degree achievements. In Tanya Matthews \& Devon Strolovitch (eds.), Proceedings of Semantics and Linguistics Theory (SALT) IX, 127-144. Ithaca, NY: Cornell University Press.

Hegedús, Veronika. 2013. Non-verbal predicates and predicate movement in Hungarian. Ph.D. dissertation, Tilburg University.

Hegedús, Veronika. 2017. P heads in Hungarian complex events. Presented at the 2nd Budapest Linguistics Colloquium, Eötvös Loránd University.

Hegedús, Veronika. 2018. Endpoint(s) in Hungarian denominal verb constructions. Presented at the Research Institute for Linguistics of the Hungarian Academy of Sciences.

Hegedús, Veronika. 2020. Back to restitutives (again): A syntactic account of restitutive and counterdirectional verbal particles in Hungarian. Acta Linguistica Academica 67.3, 319-345.

Hegedûs, Veronika \& Éva Dékány. 2017. Two positions for verbal particles: Evidence from derived particle verbs. In Anikó Lipták \& Harry van der Hulst (eds.), Approaches to Hungarian, vol. 15: Papers from the 2015 Leiden Conference, 65-94. Amsterdam: John Benjamins.

Hunyadi, László. 2002. Hungarian sentence prosody and Universal Grammar. Frankfurt am Main: Peter Lang.

Kardos, Éva. 2012. Toward a scalar semantic analysis of telicity in Hungarian. Ph.D. dissertation, University of Debrecen.

Kardos, Éva. 2016. Telicity marking in Hungarian. Glossa: A Journal of General Linguistics 1.1, 41.

Kardos, Éva. 2019. Situation aspectual properties of creation/consumption predicates. Acta Linguistica Academica 66.4, 491-525.

Kardos, Éva \& Gergely Pethő. 2019. The interaction between event structure and argument structure in light of some English and Hungarian facts. In Maria Bloch-Trojnar \& Anna Malicka-Kleparska (eds.), Valency in verbs and verb related structures, 119-139. Berlin: Peter Lang.

Kiefer, Ferenc. 2006. Aspektus és akcióminóség: különös tekintettel a magyar nyelvre [Aspect and aktionsart: with special attention to Hungarian]. Budapest: Akadémiai Kiadó.

Krifka, Manfred. 1998. The origins of telicity. In Susan Rothstein (ed.), Events and grammar, 197-235. Dordrecht: Kluwer.

Levin, Beth \& Peter Sells. 2009. Unpredicated particles. In Linda Ann Uyechi \& Lian-Hee Wee (eds.), Reality exploration and discovery: Pattern interaction in language and life, 303-324. Stanford, CA: CSLI Publications.

MacDonald, Jonathan E. 2008. The syntactic nature of inner aspect: A minimalist perspective. Amsterdam: John Benjamins.

Pereltsvaig, Asya. 2000. On accusative adverbials in Russian and Finnish. In Artemis Alexiadou \& Peter Svenonius (eds.), Adverbs and adjunction: Linguistics in Potsdam 6, 155-176. Potsdam.

Piñón, Christopher. 1994. Aspectual composition and the 'pofective' in Polish. In Sergey Avrutin, Steven Franks \& Ljiljana Progovac (eds.), Formal Approaches to Slavic Linguistics (FASL) 3, 341-373. Ann Arbor, MI: Michigan Slavic Publications.

Piñón, Christopher. 2001. Töprengtem egyet: azon, hogy mit jelent az egyet [I did some thinking about the meaning of egyet 'one.ACC']. In Marianne Bakró-Nagy, Zoltán Bánréti \& Katalin É. Kiss (eds.), Újabb Tanulmányok a Strukturális Magyar Nyelvtan és a Nyelvtörténet Köréból [New Studies on the Structural Grammar of Hungarian and Historical Linguistics], 182-198. Budapest: Osiris.

Piñón, Christopher. 2008. Weak and strong accomplishments. In É. Kiss (ed.), 91-106.

Slabakova, Roumyana. 1997. Bulgarian preverbs: Aspect in phrase structure. Linguistics 35.4, 673-704.

Slabakova, Roumyana. 2004. Effect of perfective prefixes on object interpretation: A theoretical and empirical issue. Cahiers linguistiques d'Ottawa 32, 122-142.

Smith, Carlota. 1991. The parameter of aspect. Dordrecht: Kluwer.

Surányi, Balázs. 2006. Scrambling in Hungarian. Acta Linguistica Hungarica 53.4, 393-432. 


\section{THE SYNTAX OF INNER ASPECT IN HUNGARIAN}

Surányi, Balázs. 2009. Verbal particles inside and outside vP. Acta Linguistica Hungarica 56.2-3, 201-249.

Surányi, Balázs. 2014. Structural government in pseudo-incorporation in Hungarian: Pseudo-incorporation by $v \mathrm{P}$-internal phrase-movement. Ms., Research Institute for Linguistics of the Hungarian Academy of Sciences.

Talmy, Leonard. 1985. Lexicalization patterns: Semantic structure in lexical forms. In Timothy Shopen (ed.), Language typology and syntactic description, vol. 3: Grammatical categories and the lexicon, 57-149. Cambridge: Cambridge University Press.

Tenny, Carol. 1994. Aspectual roles and the syntax-semantics interface. Dordrecht: Kluwer.

Travis, Lisa deMena. 2010. Inner aspect: The articulation of VP. Dordrecht: Springer.

Verkuyl, Henk J. 1993. A theory of aspectuality: The interaction between temporal and atemporal structure. Cambridge: Cambridge University Press.

Wechsler, Stephen. 2005. Resultatives under the 'event-argument homomorphism' model of telicity. In Nomi Erteschik-Shir \& Tova Rapoport (eds.), The syntax of aspect, 255-273. Oxford: Oxford University Press.

Authors' addresses: (Kardos)

Department of English Linguistics,

University of Debrecen, Egyetem tér 1,

4032 Debrecen, Hungary

kardoseva@unideb.hu

(Farkas)

Department of English Language and Literature, Babeș-Bolyai University, Mihail Kogălniceanu 1, 400084 Cluj-Napoca, Romania

imola.farkas@ubbcluj.ro 